DOI

\title{
ДОСВІД ВПРОВАДЖЕННЯ ПІЛОТНОГО «КРОК-2" 3 ХІРУРГІЧНИХ ХВОРОБ У НАВЧАЛЬНИЙ ПРОЦЕС СТУДЕНТІВ 6 КУРСУ ОДЕСЬКОГО НАЦІОНАЛЬНОГО МЕДИЧНОГО УНІВЕРСИТЕТУ
}

\author{
๑В. В. Грубнік, Ю. М. Кошель, В. В. Міщенко, О. І. Ткаченко \\ Одеський національний медичний університет
}

\begin{abstract}
РЕЗЮМЕ. Проаналізовано результати пілотного «Крок-2» з хірургії за 4 роки серед 1173 студентів 6 курсу. Зараховано 846 студентам (більше як 50,5 \% вірних відповідей) не зараховано 227, що склало 19 \%. Проведена додаткова робота - консультації, повторний пілотний «Крок-2», індивідуальна робота із студентами групи ризику, що позитивно позначилося на результатах ліцензійного інтегрованого іспиту з «Крок-2»-відсоток незадовільних оцінок знизився до $0,61 \%$.

КЛЮчОВІ СЛОВА: пілотний «Крок-2», групи ризику, шляхи поліпшення результатів ліцензованого інтегрованого іспиту.
\end{abstract}

Вступ. Кожного року у вищих навчальних медичних закладах України проводиться стандартизований тестовий державний іспит «Крок-2», що затверджений наказом МОК України від 14.08.98 р. № 251. Іспит проводиться Державною екзаменаційною комісією вищого навчального закладу та центром тестування професійної компетенції спеціалістів при МОЗ України. Складовою частиною державної атестації випускників $\epsilon$ тестовий іспит «Крок-2», який визначає мінімальний рівень професійної компетентності, необхідний для присвоєння кваліфікації спеціаліста [1].

Досвід попередніх ліцензійних іспитів «Крок-2» свідчить про те, що деякі випускники не завжди долають заліковий рубіж через недостатні знання, розгубленість, знервованість. Щоб мінімізувати ці причини на кафедрі хірургії № 1 Одеського національного медуніверситету впродовж навчального року проводиться пілотний «Крок-2».

Мета дослідження: 1. Привчити студентів до необхідності при вирішенні завдань вкладатись у визначений термін (1 хвилина - 1 тест).

2. Визначити серед студентів групи ризику.

3. Провести додаткову роботу із студентами групи ризику.

Матеріал і методи дослідження. На початку циклу студентів попереджають про проведення через 3-4 дні пілотного Крок-2. Студенти отримують зразок протоколу відповідей, в якому вказується номер варіанту, прізвище студента, курс, група, прізвище викладача, дата проведення. Окремо визначається кількість правильних та неправильних відповідей, а також відсоток правильних. Кожен студент отримує блок тестів «Крок-2», що містить 90 завдань. Лист протоколу поділений на 2 частини, кожна з яких містить 45 тестових завдань з варіантами відповідей - А, В, С, Д, Е [2]. Студент закреслює клітинку з вірною відповіддю. Для перевірки завдань виготовлені спеціальні шаблони протоколів на прозорій плівці, де вказані правильні відповіді для кожного варіанту. Викладач накладає плівку на лист заповненого студентом протоколу і визначає та підраховує неправильні відповіді. Перевірка однієї роботи з відповідями на 90 тестових завдань потребує 4-5 хвилин, після чого вираховується відсоток правильних відповідей та визначається, отримав студент залік чи ні. Дослідження проводили впродовж чотирьох років, з 2012 по 2016 рік.

Результати й обговорення. У 2012-2013 навчальному році із 147 студентів при проведенні пілотного «Крок-2» не здолали бар'єр у 50,5 \% 33 студенти, що склало 22,4 \%, у 2013-2014 році із 241 студента не склали залік 37, що становило 15 \%. Із 323 студентів у 2014-2015 році не зараховано 60 студентам (19\%). У 2015-2016 році із 462 студентів не зараховано 97, що склало $21 \%$.

Таким чином, з 2012 по 2016 навчальний рік завдання пілотного «Крок-2» з хірургічних хвороб вирішували 1173 студенти; з них залік було зараховано 846 студентам (рубіж 50,5 \%), не зараховано 19 \% від усієї кількості студентів. Після перевірки завдань кожен викладач отримував списки студентів, що перебували у групі ризику для проведення індивідуальної роботи з кожним студентом. Були визначені додаткові консультації, проводились повторні пілотні «Крок-2», були інформовані відповідні деканати.

Була створена база даних з тестових завдань «Крок-2», починаючи з 2002 року; ця інформація була розміщена на сайті кафедри, що дозволило студентам активно користуватись цими матеріалами у процесі підготовки до ліцензійного іспиту. Після отримання результатів ліцензійного іспиту ми порівняли динаміку рівня знань студентів групи ризику в залежності від додаткових занять. Так, якщо за 2014-2015 навчальний рік за результатами пілотного Крок-2 не отримали заліку 60 студентів, що склало $21 \%$, то за результатами 
Огляди літератури, оригінальні дослідження, погляд на проблему

ліцензійного іспиту із цієї групи ризику не склали екзамен тільки 2 студенти, що склало 0,61 \%. Якщо відсоток вірних відповідей на завдання пілотного «Крок-2» у групі ризику складав у середньому $44 \%$, то після проведеної підготовки він виріс до $75 \%$.

Висновки. 1. Проведення пілотного «Крок-2» з хірургії дозволяє визначити групи ризику серед студентів 6 курсу.

2. Проведення додаткової роботи з групами ризику (консультації, повторний пілотний
«Крок-2», індивідуальна робота) дозволяє суттєво зменшити відсоток незадовільних оцінок (до $0,61 \%)$.

3. Використання спеціальних шаблонів для перевірки тестових завдань «Крок-2» значно скорочує час перевірки контрольних завдань (до 4-5 хвилин).

Перспективи подальших досліджень. Впровадження пілотного "Крок-2» у навчальний процес студентів 6 курсу у вищих навчальних медичних закладах України.

\title{
ЛІТЕРАТУРА
}

1. Комплексный практически ориентированный государственный экзамен : практическое пособие. Одесса : Одесский медуниверситет, 2007.

2. Збірник завдань для підготовки до тестового екзамену з медичних дисциплін / за ред. чл. кор. АМН України проф. В. Ф. Москаленка. - Київ, 2005.

\section{PRACTICES FOR PILOT STEP-2 WITH SURGICAL DISEASES IN THE LEARNING PROCESS OF STUDENTS OF 6TH COURSE ODESA NATIONAL MEDICAL UNIVERSITY}

\author{
○V. V. Hrubnik. Yu. M. Koshel, V. V. Mishchenko, O. I. Tkachenko \\ Odesa National Medical University
}

SUMMARY. The result of the pilot "Step-2" practical study of surgery, for 4 years, among 1173 students of 6th courses, was analyzed. As a result - 846 students passed, 227 didn't pass, accounting $19 \%$. Additional work was carried out - consulting, re-pilot «Step-2» Individual work with students at risk, which positively affected the results licensing exam in «Step-2». The percentage of unsatisfactory ratings came down to $0.61 \%$.

KEY WORDS: pilot Step-2, ways to improve outcomes licensed integrated examinations. 